\title{
ORIENTASI PENDIDIKAN AGAMA ISLAM DI SEKOLAH UMUM
}

\author{
Syafruddin \\ Sekolah Tinggi Agama Islam (STAI) Al-Gazali Bulukumba \\ Kampus: Jl. A. Mappijalan No. 23 Bulukumba \\ Email: Syafruddin.danial@yahoo.com
}

\begin{abstract}
Abstrak:
Pendidikan Islam menghadapi banyak masalah, di antaranya orientasi nilai keagamaan dan pendekatan aplikasi. Orientasi nilai religius didasarkan pada materi Islam yang tidak dapat dipisahkan dari tujuan pendidikan islami. Tujuannya adalah menjadi "insan kamil", yang tercerminkan pada pengintegrasian nilai individu dan sosial. Oleh karena itu, orientasi nilai agama di sekolah harus berkisar antara dua belah pihak, "dimensi makhluk" (kesalehan individual) dan "dimensi khalifah" (kesalehan sosial). Untuk menanamkan nilai pendidikan Islam ke anak-anak, dapat ditangani melalui pendekatan-pendekatan berikut ini; strategi tradisional, liberal, pemberian model yang baik (uswah), dan klarifikasi nilai. Penerapan strategi harus disesuaikan dengan perkembangan anak. Terkait dengan strategi, guru pendidikan Islam harus mempertimbangkan urgensi ketepatan dalam menggunakan nilai klarifikasi. Melalui strategi ini, anak-anak akan dapat memilih, berdialog, membuat pertimbangan, dan menentukan jenis nilai apa yang dipilih. Dengan nilai ini, anak-anak akan memiliki komitmen yang kuat untuk menghadapi setiap perubahan kehidupan terutama dalam perubahan sosial.
\end{abstract}

\begin{abstract}
:
Islamic education faces many problems, among them are the religious value orientation and application approach. The religious value orientation is based on Islamic subject matters that cannot be separated from the aim of Islamic education. Its aim is to become a "perpect man", that reflects on the integration of individual and social values. Therefore, the religious value orientation in school must be revolved between the two sides, "Abdullah dimention" (individual religiosity) and "khalifah dimention" (social religiosity). To instill the value of Islamic education to children, it can be handle through the following approaches; traditional strategy, liberal, providing a good model (uswah), and value clarification. To implement these strategies, it must be adjusted to the child's development. Concerning with the strategy, the teacher should consider the urgency of Islam on the use of value clarification. With these strategies, the children will be able to choose, to make a dialogue, to make a consideration,, and to determine the type of value to be applied. With this value, the children will have a strong commitment to deal with any change of life, especially in social change.
\end{abstract}

Kata kunci:

Nilai Keagamaan, Penanaman Nilai, Orientasi

DALAM ajaran Islam, manusia adalah makluk ciptaan Tuhan yang paling mulia melebihi makhluk-makhluk lainnya (QS al-Israā'/17: 70):

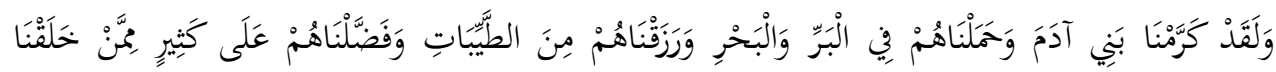

$$
\begin{aligned}
& \text { تَفْضِيلا (V) }
\end{aligned}
$$


Dan sesungguhnya telah Kami muliakan anak-anak Adam. Kami angkat mereka di daratan dan di lautan. Kami beri mereka rezeki dari yang baik-baik dan Kami lebihkan mereka dengan kelebihan yang sempurna atas kebanyakan makhluk lain yang telah Kami ciptakan.

Kelebihan itu ialah bahwa pada manusia diberikan potensi berupa daya akal untuk menata hidup dan kehidupannya, dalam arti membentuk peradaban menjadi makhluk yang beradab. Sedangkan pada makhluk lain seperti binatang potensi itu tidak diberikan. Potensi akal y diberikan kepada manusia mampu menciptakan dunia kehidupannya sendiri, dan menetapkan nilai-nilai luhur yang ingin dicapai lengkap dengan pilihan srategi untuk mencapai cita-cita hidupnya. Kemampuan yang demikian itu tidak dimiliki oleh binatang, apalagi tumbuh-tumbuhan dan benda mati lainnya. Bagi binatang dan makluk hidup lain, hidup dan kehidupan adalah sama. Keduanya berada dalam tangan Tuhan secara langsung menurut sunnatullah, yaitu hukum alam ciptaan Tuhan yang berjalan secara pasti, tidak dapat diubah dan tidak mengenal perubahan, (QS. Al-Fath: 23). Sedangkan bagi manusia, hidup tidak semata di tangan Tuhan, tetapi kehidupan manusia juga banyak dipengaruhi oleh ikhtiar manusia dalam memanfaatkan potensi akalnya. Baik buruknya nasib manusia di dunia ini sangat tergantung pada manusia itu sendiri. (QS al-Ra'd/13: 11).

Untuk memajukan kehidupan tersebut, manusia diperintahkan untuk belajar secara terus menerus selama hidupnya. Tuhan juga menetapkannya sebagai khalifah dan pengelola di muka bumi, dan memanfaatkan semua yang ada untuk kemajuan dan kesejahteraan hidupnya dalam rangka memenuhi tujuan yang satu, yaitu mengabdi kepada Pencipta-Nya, ${ }^{1}$ sebagai dinyatakan dalam QS al-Zariyat/51: 56:

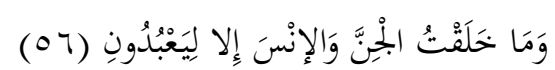

Dan tidaklah Aku menciptakan jin dan manusia melainkan untuk mengabdi kepada-Ku.

Ayat tersebut antara lain yang melatarbelakangi keyakinan yang mendasar bahwa seluruh proses kehidupan manusia ditandai dengan kegiatan pembelajaran atau pendidikan. Hal ini senada dengan pernyataan Ruppert C. Lodge yang menyatakan bahwa hidup adalah pendidikan dan pendidikan adalah hidup. ${ }^{2}$

Salah satu realitas kependidikan yang telah membudaya di kalangan sebagian bangsa, terutama di kalangan sebagian besar umat Islam adalah Pendidikan Agama Islam. Kenyataan yang dapat disaksikan di lembaga sekolah, pola pengajaran bidang studi Pendidikan Agama Islam terpusat pada penumpukan pengetahuan. Pengajaran itu mengabaikan pembentukan "afektif".

Pendidikan agama diharapkan menjadi sumber kekuatan dan inspirasi moral untuk menumbuhkan bangsa yang berbudi luhur. Khusus Pendidikan Agama Islam, diharapkan dapat membentuk insan kamil; gambaran kepribadian yang memadukan potensi fikir dan dzikir atau manusia yang memiliki "kesalehan ritual" dan "kesalehan aktual". Pokok masalah dari hal tersebut adalah proses dan isi nilai keagamaan (Pendidikan Agama Islam) yang tidak jelas arahnya. Apakah proses dan isi pendidikan 
Agama Islam hendak diarahkan ke peserta didik yang memiliki "kesalehan ritual", atau yang berorientasi pada nilai Abdillah? Atau apakah proses dan isi pendidikan Agama Islam hendak diarahkan ke peserta didik yang memiliki "kesalehan aktual", atau pengembangan yang berorientasi pada nilai kekhalifahan?, atau hendak mengintegrasikan keduaduanya menjadi manusia paripurna (insan kamil).

Kajian ini berfokus pada orientasi nilai keagamaan dalam lembaga pendidikan formal (sekolah umum), maka sebagai pisau analisis utama untuk menafsirkan setiap informasi adalah ilmu filsafat pendidikan.

\section{BATASAN: NILAI KEAGAMAAN}

Dalam Encyclopedia Britannica dikatakan bahwa: "Value is a determination or quality of object which involves any sort or appriciation or interest". ${ }^{3}$ Artinya, nilai adalah suatu yang menentukan atau suatu kualitas obyek yang melibatkan suatu jenis atau apresiasi atau minat.

Menurut Milton dan James Bank, nilai adalah suatu tipe kepercayaan yang berada dalam ruang lingkup sistem kepercayaan, dalam mana seseorang harus bertindak atau menghindari suatu tindakan, atau mengenai sesuatu yang pantas atau tidak pantas dikerjakan, dimiliki, dan dipercayai. ${ }^{4}$ Dengan demikian, nilai merupakan preferensi yang tercermin dari perilaku seseorang sehingga ia akan melakukan atau tidak melakukan sesuatu tergantung pada sistem nilai yang dipegangnya. Jadi, nilai adalah konsep, sikap, dan keyakinan seseorang terhadap sesuatu yang dipandang berharga olehnya.

Seandainya "nilai" itu dihubungkan dengan "agama" yang dikenal pula dengan sebutan "nilai religi" atau "nilai keagamaan" maka pengertianya adalah tingkatan integritas kepribadian yang mencapai tingkat budi yang bersifat mutlak kebenaranya, universal dan sesuai. ${ }^{5}$ Nilai agama atau nilai keagamaan atau nilai religi tersebut kemudian ditransmisikan lewat pendidikan. Sebab salah satu fungsi pendidikan menurut Abdullah Fadjar ialah mentransmisikan nilai-nilai. ${ }^{6}$ Dalam konteks pendidikan Islam maka nilai-nilai Islam itulah yang ditransmisikan.

Pendidikan Islam di sini tidak hanya dipahami sebatas "ciri khas" jenis pendidikan yang berlatar belakang keagamaan. Tetapi, pendidikan Islam menurut Zarkawi Soejoeti sebagaimana diungkapkan oleh A. Malik Fadjar,7 berarti: pertama, jenis pendidikan yang pendirian dan penyelengaraanya didorong oleh hasrat dan semangat cita-cita untuk mengejawantahkan nilai-nilai Islam, baik yang tercermin dalam nama lembaganya maupun dalam kegiatan-kegiatan yang diselenggarakanya. Di sini, kata Islam ditempatkan sebagai sumber nilai. Kedua, jenis pendidikan yang memberikan perhatian dan sekaligus menjadikan ajaran Islam sebagai pengetahuan untuk program studi yang diselenggarakanya. Di sini, kata Islam ditempatkan sebagai bidang studi, sebagai ilmu, dan diperlakukan seperti ilmu lain. Ketiga, jenis pendidikan yang mencakup kedua pengertian itu. Di sini, kata Islam ditempatkan sebagai sumber nilai dan sebagai bidang studi yang ditawarkan lewat program studi yang diselenggarakannya. 
Dari pengertian yang diberikan Zarkawi itu, kiranya bisa lebih dipahami bahwa keberadaan pendidikan Islam tidak sekedar menyangkut persoalan ciri khas, melainkan lebih mendasar lagi, yaitu tujuan yang diidamkan dan diyakini sebagai yang paling ideal. Tujuan yang diidamkan menurut Maududi sebagaimana dikutip oleh Ismail SM adalah menyiapkan siswa agar mampu mengemban misi yang diberikan oleh Allah, yakni sebagai khalifah dan 'abid. ${ }^{8}$ Rumusan tersebut sejalan dengan apa yang dikemukakan oleh Ali Ashraf, "The ultimate aim of muslim education lies in the realization of complete submission to Allah on the level of the individual, the community and humanity at large". 9 Ungkapan tersebut berarti tujuan tertinggi dari pendidikan muslim adalah merealisasikan kepasrahan penuh pada Allah pada tingkat individual, komunitas, dan umat. Hal itu senada dengan ungkapan A. Malik Fadjar ${ }^{10}$ yang diistilahkan dengan "insan kamil" atau "muslim paripuma". Fungsi sebagai khalifah dan 'abid tersebut merupakan satu kesatuan yang tidak dapat dipisahkan sehingga harus dicapai secara bersamaan. Tujuan itu sekaligus mempertegas bahwa misi dan tanggung jawab yang diemban pendidikan Islam lebih berat lagi. Tujuan pendidikan Islam itu bersifat universal. Hal ini dapat dipahami dari pernyataan Abdurrahman Saleh Abdullah sebagai berikut "The general educational aims are fixed and are not liable to change from time to time. The finality of the prophethood implies the finality of ideals preached by Muhammad".11 Artinya "Tujuan umum pendidikan Islam adalah pasti dan tidak terkena perubahan dari waktu ke waktu. Finalitas kenabian secara implisit menyatakan finalitas cita-cita yang diajarkan oleh Nabi Muhammad SAW kepada sekalian manusia". Menurut Abdul Rahman an-Nahlawi, pendidikan Islam adalah pendidikan yang menyeluruh, tidak terbatas kepada ibadat dan melupakan tingkah laku, atau memberatkan individu dan melupakan amal, tetapi meliputi segala kehidupan manusia. ${ }^{12}$ Oleh karena itu, berdasarkan orientasinya, menurut Nurcholish Madjid (nilai keagamaan dapat mengarahkan kepada dua dimensi hidup manusia, yaitu: (1) Dimensi Ketuhanan, yakni penanaman rasa taqwa kepada Allah, kesalehan ritual atau nilai Abdillah (2) Dimensi kemanusiaan, yaitu pengembangan kemanusian kepada sesama, mengarahkan kepada nilai kemajuan, pengembangan, dan kesalehan aktual atau nilai kekhalifahan. ${ }^{13}$

\section{Abdillah}

Hubungan antara manusia dengan Tuhan dalam bentuk ibadah adalah kewajiban sebagai hamba Allah atau Abdillah. Sebagai hamba Allah, posisi manusia wajib menerima dan menjalankan perintah Tuhan serta menjauhi dan meninggalkan sesuatu yang dilarang-Nya yang dalam bahasa Agama disebut takwa. Dalam menghambakan diri pada Tuhan, yang ditekankan pada ibadah adalah keikhlasan dan mencari ridla-Nya. Manusia sebagai Abdillah yang senatiasa beribadah, tidak sekedar menjalankan perintah dan menjauhi larangan-Nya, melainkan harus didasari atas keyakinan dalam hati seseorang bahwa hidup dan keberadaanya adalah milik Allah semata-mata. ${ }^{14}$ Oleh karena itu, segala aktivitasnya mestilah disesuikan dengan kehendak pemilik dari kehidupan ini sehingga semua aktivitasnya akan bernilai ibadah. 
Tuhan, Sang Pemilik Yang Maha Melihat dan Menghitung perbuatannya, akan meminta pertanggung-jawaban atas apa yang telah dilakukan di dunia. Pertanggungjawaban ini akan dimintakan di hari akhir. Sehubungan dengan itu, kepecayaan kepada adanya hari akhir itu seringkali disebutkan mengikuti penyebutan keimanan kepada Allah.

Segala upaya manusia untuk memajukan kehidupanya dalam rangka memenuhi tujuan yang satu, yakni mengabdi kepada Pencipta-Nya, sebagaimana dinyatakan dalam Surat al-Zariyaat/51: 56:

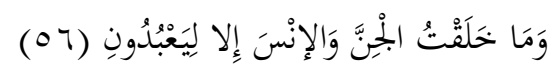

Dan tidaklah Aku menciptakan jin dan manusia melainkan untuk mengabdi kepada-Ku.

Posisi manusia sebagai Abdillah, mengisyaratkan bahwa manusia senantiasa taat kepada Tuhan yang tergambar dalam sosok kepribadian adanya kesalehan ritual, meskipun dalam diri manusia terdapat unsur kebebasan dan kemandirian.

Dalam bahasa Al-Qur'an, dimensi hidup Ketuhanan ini disebut jiwa rabbaniyah (QS Ali ‘Imran/3: 79) atau ribbiyah (QS Ali ‘Imran/3: 147). Jika merinci apa saja wujud nyata atau substansi jiwa ketuhanan itu, diperoleh nilai keagamaan pribadi yang amat penting dan mendasar. Menurut Nurcholish Madjid, nilai-nilai keagamaan yang mendasar tersebut antara lain: (l) Iman, yaitu sikap batin yang penuh kepercayaan kepada Tuhan, (2) Islam, yaitu sikap pasrah kepada Allah, (3) Ihsan, yaitu kesadaran yang sedalam-dalamnya bahwa Allah senantiasa hadir atau berada bersama kita di mana pun kita berada, (4) Takwa, yaitu sikap yang sadar penuh bahwa Allah selalu mengawasi, kemudian manusia berusaha berbuat hanya sesuatu yang diridlai Allah, dengan menjauhi atau menjaga diri dari sesuatu yang tidak diridlai-Nya, (5) Ikhlas, yaitu sikap murni dalam tingkah laku dan perbuatan, semata-mata demi memperoleh ridla Allah, (6) Tawakal, yaitu sikap senantiasa bersandar kepada Allah, dengan penuh harapan kepada-Nya dan keyakinan bahwa Dialah penolong dalam mencari dan menemukan jalan yang terbaik, (7) Syukur, yaitu sikap penuh rasa terima kasih dan penghargaan, dalam hal ini atas segala nikmat dan karunia yang tidak terbilang banyaknya, yang dianugerahkan Allah kepada manusia, dan (8) Sabar, yaitu sikap tabah menghadapi segala kepahitan hidup. ${ }^{15}$

Tentu saja masih banyak lagi nilai-nilai dasar keagamaan pribadi yang diajarkan dalam Islam. Namun kiranya hal yang disebutkan di atas cukup mewakili nilainilai keagamaan mendasar yang perlu ditanamkan kepada anak didik, sebagai bagian yang penting dari pendidikan keagamaan. Biasanya orang tua atau pcndidik dapat mengembangkan pandangan tersebut sehingga meliputi nilai-nilai keagamaan lainya, sesuai dengan perkembangan anak.

Dari hal tersebut, nilai yang terkandung dalam 'abdillah adalah keterikatan, loyalitas mutlak terhadap kehendak penciptanya, tanpa melepaskan dari perkembangan jaman. 


\section{Khalifah}

Di samping berkedudukan sebagai abdillah, manusia mempunyai tugas sebagai khalifah (wakil Tuhan) di bumi yang memiliki kedudukan yang tinggi dan mulia (QS al-Baqarah/2: 30). Sebagai khalifah Tuhan, manusia diberi tugas dan tanggung jawab untuk memakmurkan kehidupan di bumi (QS Hud/11: 61). Tugas sebagai khalifah di bumi harus dilakukan oleh manusia dengan moralitas yang baik sesuai dengan kehendak Tuhan dan senantiasa mendekatkan diri kepada Tuhan. Ini berarti sebagai khalifah Tuhan di muka bumi, manusia juga sekaligus memposisikan diri sebagai abdillah yang bersedia menerima dan menjalankan perintah Tuhan dan menjauhi larangan-larangan-Nya (kebebasan dan kemandirian dalam keterikatan).

Terminologi khalifah fil ard (QS aI-Baqarah/2: 30) merupakan dekrit abadi yang memberi wewenang dan kedaulatan manusia sebagai wakil Tuhan, karena Tuhan memberi berbagai potensi/kemampuan berkenaan dengan sifat-sifat Tuhan. ${ }^{16}$ Misalnya, Tuhan Maha Pencipta, maka manusia juga memiliki sifat seperti yang dimiliki oleh Tuhan tersebut, manusia mampu mencip-takan sesuatu, dalam arti mengembangkan yang sudah ada. Citra ideal Tuhan seperti yang terangkum dalam Asmaul Husna tidak mungkin terjangkau secara purna oleh manusia. Kemampuan manusia hanya sejauh yang telah dicontohkan oleh Rasulullah sebagai uswatun hasanah, Dalam rangka mencari simbul identitas moral yang mutlak sempurna (Allah), manusia dapat mengambil potret utuh insan kamil, yang terjelma pada pribadi Nabi Muhammad saw. (QS al-Nahl/16: 78). Potret insan kamil adalah gambaran kepribadian yang memadukan potensi pikir dan dzikir. Menurut Iqbal, tujuan seluruh kehidupan adalah membentuk insan kamil atau manusia yang mulia dan setiap pribadi hendaklah berusaha untuk mencapainya. Cita-cita membentuk manusia utama ini memberikan kepada kita ukuran "baik" dan "buruk". Apa yang dapat memperkuat pribadi, baik sifatnya dan yang dapat melemahkan pribadi, buruk sifatnya. ${ }^{17}$

Doktrin tentang khalifah yang disebutkan dalam al-Qur'an ialah bahwa segala sesuatu di atas bumi ini, seperti daya dan kemampuan untuk berbuat, hanyalah karunia dari Allah swt. Dia telah menjadikan manusia sedemikian rupa hingga ia dapat menggunakan pemberian dan karunia tersebut sesuai dengan keridlaan-Nya. Berdasarkan hal ini maka manusia hanyalah wakil Sang Pemilik yang sebenarnya. Namun, status khalifah di sini tidak memiliki fungsi apa-apa selama ia tidak mengikuti hukum-hukum Sang Pemilik yang sebenarnya. Seorang Psikolog Jerman, Carl Gustav Jung, sebagaimana dikutip oleh Djamaludin Ancok, menyatakan bahwa perhatian pada kehidupan materi dan melupakan ajaran agama adalah pangkal dari kehancuran umat manusia. ${ }^{18}$ Sejalan dengan hal tersebut, Maslow menyatakan bahwa penyakit utama abad kita ialah tiadanya nilai-nilai, keadaan ini jauh lebih gawat dari yang pernah terjadi dalam sejarah umat manusia; dan sesuatu dapat dilakukan dengan usaha umat manusia sendiri. ${ }^{19}$

Dari hal tersebut tampak bahwa nilai-nilai kekhalifahan merupakan dimensi kemanusiaan tentang nilai-nilai budi luhur, tentang nilai-nilai yang mewujud nyata dalam tingkah laku dan budi pekerti sehari-hari atau al-akhlaq al-karimah. Secara ope- 
ratif nilai-nilai akhlak menurut Nurcholish Madjid antara lain: (1) Silaturrahmi, yaitu pertalian rasa cinta kasih antara sesama manusia, (2) Persaudaraan, yaitu semangat persaudaraan, (3) Persamaan, yaitu pandangan bahwa semua manusia adalah sama dalam harkat dan martabat, (4) Adil, yaitu wawasan yang "seimbang" dalam memandang, menilai, atau menyikapi sesuatu atau seseorang, (5) Baik sangka, yaitu sikap penuh baik sangka kepada sesama manusia, (6) Rendah hati, yaitu sikap yang tumbuh karena keinsafan bahwa segala kemuliaan hanya milik Allah, karenanya tidak sepantasnya manusia "mengklaim" kemuliaan itu kecuali dengan pikiran yang baik dan perbuatan yang baik yang itu pun hanya Allah yang akan menilainya, (7) Tepat janji, yaitu salah satu sifat orang yang benar-benar beriman ialah sikap selalu menepati janji bila membuat perjanjian, (8) Lapang dada, yaitu sikap penuh kesediaan menghargai orang lain dengan pendapat-pendapat dan pandangan-pandanganya, (9) Dapat dipercaya, yaitu penampilan diri yang dapat dipercaya, (10) Perwira, yaitu sikap penuh harga diri namun tidak sombong, (11) Hemat, yaitu sikap tidak boros dan tidak pula kikir dalam menggunakan harta, dan (12) Dermawan, yaitu sikap suka menolong sesama manusia. ${ }^{20}$

Dari uraian-uraian tersebut dapat diambil pengertian bahwa nilai yang terkandung dalam kekhalifahan antara lain: kebebasan, kemandirian, kreatif, dinamis, dan mengutamakan kemajuan.

\section{PENANAMAN NILAI DI SEKOLAH}

\section{Proses dan Isi}

Sekolah merupakan bentuk formalisasi pendidikan. Pendidikan tidak hanya sekedar mempertahankan nilai-nilai, tetapi juga sekaligus mengembangkan nilai-nilai sehingga anak didik mampu mengembangkan diri sejalan dengan perkembangan jaman dengan identitas kepribadian yang kokoh. Penanaman nilai mempunyai arti menjaga stabilitas masyarakat yang diperlukan untuk pelestarian nilai, tetapi dalam kehidupan modern yang berubah dengan cepat dibutuhkan adanya upaya pengembangan nilai agar tidak tertinggal dari perubahan yang terjadi.

Pendidikan dipandang sebagai wahana yang efektif untuk membantu subyek didik berkembang ke tingkat yang normatif lebih baik dengan cara atau jalan yang normatif juga baik. ${ }^{21}$ Persoalan nilai menyangkut proses dan isi. Proses adalah berkaitan persoalan bagaimana nilai itu ditanamkan kepada anak didik sehingga pendidik dan model atau strategi yang digunakan akan berpengaruh pada proses penanaman nilai di sekolah. Nilai yang berkaitan dengan isi adalah menyangkut persoalan nilai apa yang hendak diajarkan dan dari mana sumber nilai itu diambil. Berkaitan dengan nilai keagamaan, maka nilai itu terdapat dalam mata pelajaran Pendidikan Agama Islam.

Sejalan dengan hal tersebut, yang perlu mendapat perhatian serius adalah mengenai kualitas pendidikan yang mana hal ini bersangkutan erat dengan mutu materi yang akan disampaikan serta mutu para guru atau pendidiknya. ${ }^{22}$ Yang menjadi persoalan pokok adalah bagaimana kualitas para guru atau pendidikanya? Sebab, jika 
kualitas gurunya tidak bermutu maka proses penerapan dan internalisasi nilai-nilai agama tidak akan berhasil dengan baik. Kualitas guru atau pendidik dalam hal ini adalah menyangkut penguasaan ilmu dan perbuatan (akhlak dan amalan).

Dalam proses pembelajaran yang di dalamnya terdapat interaksi edukatif sering ditemukan guru yang punya peran dominan dalam proses pembelajaran, bahkan cenderung semua berpusat pada guru (teacher centered). Guru terkesan otoriter. Apa yang disampaikan oleh guru dianggapnya sebagai kebenaran yang dianggap mutlak, murid hanya sekedar menerima informasi, pengetahuan, bahkan nilai dan akhirnya menjadi miliknya. Dalam bentuk seperti ini, orientasinya adalah "anak memiliki" atau "to have" nilai, anak sekedar pasif menerima tanpa mempersoalkannya. Bentuk interaksi yang lain adalah berpusat pada murid (student centered). Di sini yang sangat dominan adalah murid, sedangkan guru sebagai fasilitator yang mengarahkan nilainilai untuk siswanya. Bentuk seperti ini memberikan kebebasan kepada murid untuk mencari dan berkreasi serta aktif dalam proses pembelajaran. Orientasi model ini adalah menjadikan "anak itu menjadi" atau "to be", murid tidak sekedar aktif menerima nilai tetapi juga sekaligus mengembangkan nilai. Dua kutub model interaksi tersebut tentunya tidak selalu dipertentangkan. Ini tergantung pada tingkat perkembangan anak didik.

Di samping dua model interaksi tersebut, berkaitan dengan penanaman nilai, maka patut direnungkan model yang ditawarkan oleh Noeng Muhadjir yaitu model interaksi humanistik, yaitu interaksi pendidik dengan subyek-didik diharapkan tumbuh berlandaskan pemahaman subyek-didik terhadap diri sendiri dan perilaku pendidiknya. ${ }^{23}$ Model ini sepadan dengan sebutan pengajaran humanistik atau pendidikan afektif.

\section{Pendekatan Pendidikan Nilai}

Penanaman nilai kepada anak didik sudah barang tentu disesuaikan dengan taraf perkembangan anak tersebut. Suatu model pendekatan tertentu mungkin hanya sesuai untuk suatu tahap perkembangan anak, tetapi belum tentu cocok untuk tahap perkembangan lain. Dalam pembahasan pendidikan nilai terdapat berbagai pendekatan yang dikemukan oleh para ahli.

Una Kartawisastra, $\mathrm{dkk}^{24}$ mengemukanan empat strategi, yaitu:

\section{Strategi Tradisional}

Dalam strategi tradisional ini pembentukan nilai dengan jalan memberi nasehat atau indoktrinasi. Para orang tua atau guru yakin akan nilai-nilai baik/luhur yang dianutnya karena itu mereka menghendaki agar anak didiknya juga memiliki nilai-nilai tersebut. Strategi yang ditempuh adalah memberitahukan secara langsung nilai-nilai mana yang baik, kurang baik, atau tidak baik.

\section{Strategi Bebas atau Liberal}

Strategi bebas ini ialah memberikan kebebasan sepenuhnya kepada anak untuk memilih dan menentukan sendiri nilai-nilai yang akan diambilnya. Asumsi dari stra- 
tegi ini adalah belum tentu nilai yang baik bagi seseorang baik pula bagi orang lain. Dengan demikian, anak atau siswa dibiarkan untuk memilih nilai yang sesuai untuk dianut dan diyakini oleh dirinya sendiri, tanpa adanya campur tangan dari guru atau orang lain.

\section{Strategi Memberi Contoh}

Orang tua atau guru yang telah meyakini benar nilai-nilai yang dianutnya akan bertingkah laku sesuai dengan nilai-nilai tersebut. Dalam hal ini, pembentukan nilai dapat melalui dua teknik. Pertama, memberi contoh dalam tingkah laku yang sesuai dengan nilai-nilai yang dianut. Kedua, mengajarkan nilai-nilai sehingga anak dapat membedakan nilai-nilai yang baik dan yang tidak baik, atau nilai-nilai yang boleh dianut dan yang terlarang.

\section{Strategi Klarifikasi Nilai}

Pendekatan ini merupakan salah satu usaha untuk membentuk anak dalam menentukan nilai-nilai yang akan dipilihnya yang juga merupakan pelengkap dari strategi memberi contoh. Strategi ini sebenarnya secara tidak sadar sudah sering digunakan, akan tetapi secara sistematis ini dikembangkan oleh: Louis Raths, dengan bertitik tolak dari pemikiran John Dewey. Pendekatan ini bukan meneliti nilai-nilai mana yang dianggap baik, melainkan dititikberatkan pada proses pengambilan nilai. Hal yang demikian ini seperti apa yang diungkapkan oleh Barry Chazan sebagai berikut: "Thus, we should not teach children a bag of values or virtues; instead, we should teach them a"process of valuing", ${ }^{25}$ Artinya "Jadi, kita tidak boleh mengajarkan pada anak-anak tentang serangkaian nilai atau kebaikan tertentu; sebaliknya, kita perlu mengajarkan pada mereka tentang "proses penilaian". Dalam pendekatan ini guru berperan sebagai orkestrator dari situasi pembelajaran yang memungkinkan terjadinya perkembangan sub-proses penilaian dasar yang lebih rinci, guru lebih berfungsi sebagai teknisi yang mendorong perkembangan serangkaian keahlian teknis. Proses pengambilan nilai melalui strategi klarifikasi nilai menurut Douglas Superka adalah: (1) Memberikan kebebasan untuk mengekspresikan secara spontan, (2) Memberikan dorongan untuk mengikuti atau melakukan sesuatu, (3) Membina kesadaran dan mengidentifikasikan nilainya sendiri, (4) Memberikan alasan, pertimbangan atau penalaran, (5) Menggunakan pola berpikir secara logis dan analitis, (6) Memberikan penjelasan-penjelasan mengenai nilai-nilai, (7) Berpartisipasi dalam sesuatu nilai atau perbuatan, dan (8) Mengintegrasikan diri.

Sedangkan penanaman nilai sampai pada internalisasi nilai dalam diri anak didik, proses internalisasi isinya (nilai hidup) dapat menggunakan model penjenjangan yang ditempuh dan disarankan oleh Krathwold dan kawan-kawan sebagaimana dikutip oleh Noeng Muhadjir. Model tersebut meliputi 5 jenjang, yaitu: (1) menyimak, (2) menanggapi, (3) memberi nilai, (4) mengorganisasi nilai, dan (5) karakterisasi nilai. 26

Selanjutnya menurut Miller terdapat lima model pengenalan atau pembentukan diri, yaitu; (1) value clarification atau penjernihan nilai-nilai, (2) identity education atau 
pendidikan jati diri, (3) classroom meeting-model atau model pertemuan kelas, (4) role playing atau permainan peranan, dan (5) self-directed model atau model belajar mengarahkan diri sendiri. ${ }^{27}$

\section{ORIENTASI PENANAMAN NILAI KEAGAMAAN DI SEKOLAH}

Filsafat pendidikan theocentric memandang bahwa semua yang ada diciptakan oleh-Nya, berjalan menurut hukum-hukum-Nya, dan kembali pada kebenara-Nya. ${ }^{28}$ Filsafat ini memandang bahwa manusia dilahirkan sesuai dengan fitrahnya dan perkembangan selanjutnya tergantung pada lingkungan dan pendidikan yang diperolehnya. Dalam hal memberikan pendidikan agama kepada anak sejak masa dininya sampai anak mampu berpikir, ditempuh melalui kebiasaan-kebiasan yang menyenangkan, sekalipun mereka belum mengerti maksudnya.

Kemudian dalam perkembangan selanjutnya baru diberi penjelasan sesuai dengan tahap perkembangan pemikiranya dan akhirnya pelajar sendirilah yang belajar sedang pendidik hanya membantunya. Mengenai nilai yang mendasari kegiatan proses pembelajaran, filsafat pendidikan theocentric mendasarkan kegiatan pendidikan pada tiga nilai kunci: ibadah, ikhlas, dan ridla Tuhan. ${ }^{29}$

Pemikiran di atas menunjukkan bahwa hidup dan kehidupan manusia sudah ditentukan oleh Tuhan, manusia hanya mencari hikmah atas kehidupanya. Nilai agama ditanamkan untuk membentuk kesalehan ritual atau berorientasi pada penghambaan manusia kepada Tuhan (abdillah).

Filsafat anthropocentric mendasarkan ajaranya pada hasil pemikiran manusia dan berorientasi pada kemampuan manusia dalam hidup keduniawian. ${ }^{30}$ Pendidikan diarahkan pada pembentukan dan pengembangkan kepribadian anak untuk mencapai kedewasaan dan kesejahteraan hidup duniawi. Dalam paham ini, tergambar adanya kebebasan dan kemandirian manusia dalam mengurus kehidupannya. Meskipun demikian, paham anthropocentric juga mengakui adanya keterikatan. Dalam hidup tidak ada kebebasan tanpa ikatan atau bebas tetapi terikat. ${ }^{31}$

Pemikiran di atas menunjukan bahwa hidup ditentukan oleh Tuhan sedangkan kehidupan manusia lebih banyak ditentukan oleh manusia sendiri. Manusia dengan potensi akalnya diberi kebebasan secara mandiri untuk mengurus kehidupan, kemajuan, dan kesejahteraannya. Nilai agama yang diajarkan lebih diorentasikan pada kesalehan aktual atau nilai kekhalifahan. Dalam sejarah teologi Islam, terdapat dua aliran ekstrim yang berdiri berhadap-hadapan dan bertentangan satu terhadap yang lain, yaitu paham Jabariah dan Qodariah. Paham Jabariah mengagumkan wahyu dan menganggap manusia tidak memiliki kewenangan dalam mengatur kehidupan. Paham ini berpegang pada prinsip bahwa manusia tidak mempunyai kebebasan memilih untuk menentukan jalan hidupnya. Ia memandang apa pun yang diperbuat oleh manusia merupakan keterpaksaan dalam menghadapi ketentuan Tuhan. Sebaliknya, paham Qodariah mengagumkan kemampuan akal dan menganggap manusia memiliki kewenangan besar sekali dalam mengatur kehidupanya. Paham ini berpegangan pada prinsip kebebasan manusia untuk memilih dan menentukan jalan hidupnya. ${ }^{32} \mathrm{Ke}-$ 
mudian dalam perkembangan selanjutnya, muncul aliran Asy'ariah yang menampilkan diri sebagai paham tengah antara Qodariah dan Jabariah. Paham Asy'ariah berpendapat bahwa manusia wajib berusaha, namun didasarkan pula bahwa usahanya itu tidak berpengaruh terhadap jalan kehidupan manusia yang telah ditentukan Tuhan. ${ }^{33}$

Uraian di atas tidak dimaksudkan untuk menyamakan paham theocentric dengan Jabariah dan paham anthropocentric dengan Qodariah. Tetapi, untuk mengingatkan kepada kita bahwa setiap paham itu tentu ada pengikutnya, meskipun pengikut itu sendiri, sadar atau tidak, telah mengikuti paham yang bersangkutan.

Penanaman nilai keagamaan (Islam) di sekolah tentunya tidak sekedar diarahkan kepada kesalehan ritual (abdillah), atau diarahkan kepada kesalehan aktual (khalifah), akan tetapi juga kesalehan ritual dan kesalehan aktual secara integratif, sehingga dimungkinkan terwujudnya peserta didik yang mempunyai nilai insan kamil, gambaran kepribadian yang memadukan antara potensi pikir dan zikir.

Berdasarkan praktek pendidikan, setiap orientasi pendidikan menurut Zamroni dapat dikaji berdasarkan empat dimensi yang ada, yakni dimensi status anak didik, dimensi peran guru, dimensi materi pengajaran, dan dimensi manajemen pendidikan. ${ }^{34}$ Dengan meminjam pendapat Zamroni tersebut, maka orientasi penanaman nilai keagamaan di sekolah dapat dilihat dari materi pendidikan agama yang tertuang dalam kurikulum, proses pembelajaran, dan pandangan siswa terhadap nilai-nilai keagamaan yang diberikan di sekolah.

\section{SIMPULAN}

Dari uaraian tersebut di atas, maka pada dasarnya Pendidikan Agama Islam sebagai mata pelajaran di sekolah mempunyai kedudukan yang strategis untuk mewujudkan terbentuknya "insan kamil", kepribadian yang memadukan dimensi abdillah dan khalifah. Isi Pendidikan Agama Islam yang diberikan sudah barang tentu disusun dan diberikan diorientasikan kepada antara dua kutub dimensi, yaitu dimensi abdillah atau kesalehan individual dan dimensi khalifah atau kesalehan aktual.

Sedangkan pendekatan yang dapat digunakan dalam penanaman nilai Pendidikan Agama di sekolah di antaranya, strategi tradisional, liberal, memberi contoh, dan klariflkasi nilai. Penggunaan strategi tersebut tentunya tidak lepas dari pertimbangan perkembangan anak. Yang perlu dipertimbangkan bagi guru Agama Islam adalah perlunya menggunakan strategi klariflkasi nilai karena dengan strategi ini, anak didik dibiasakan memilih, mendialogkan, mempertimbangkan dan memutuskan nilai mana yang akan dipegangnya. Dengan demikian, nilai yang dimiliki oleh anak didik menjadi kokoh terhadap berbagai perubahan yang semakin cepat.

\section{CATATAN AKHIR}

1. Sahirul Alim. Mengenal Keterpaduan Sains, Teknotogi \& Islam, Yogyakarta: Titipan Ilahi Pres, 1999, h.72.

2. Mastuhu. Dinamika Sistem Pendidikan Pesantren, Jakarta: INIS, 1994, h. 2.

3. Encyclopedi Britannica, Vol. 28, h. 963. 
4. Una Kartawisastra. Strategi Klasifikasi Nilai, Jakarta: P3R, 1980, h. 1.

5. Muh. Noor Syam. Filsafat Pendidikan dan Dasar Filsafat Pendidikan Pancasila, Surabaya: Usaha nasional, 1986, h. 133.

6. Abdullah Fadjar; "Model Transmisi Nilai-Nilai Islam" dalam Jumal Ilmu Pendidikan Islam, No. 2,Vol. 1, Yogyakarta: FakuItas Tarbiyah, 1991, h. 73.

7. A. Malik Fadjar: "Pengembangan Pendidikan Islam" dalam Kontekstualisasi Ajaran Islam, Jakarta: IPHI \& Paramadina, 1993, h. 507-508.

8. Ismail SM, dkk. Paradigma Pendidikan Islam, Yogyakarta: Pustaka Pelajar, 2001, h. 131.

9. Ali Ashraf, Crisis in Muslim Education, Jeddah: King Abdul Aziz University, 1398, h. 44.

10. Malik Fadjar, "Pengembangan Pendidikan Islam" dalam Kontekstualisasi Ajaran Islam, Jakarta: IPHI \& Paramadina, 1993, h. 508.

11. Abdurrahman Saleh Abdullah, "Educational Theory Quranic Outlook" Umm al-Qurr' University, 1982, h. 131.

12. www.alsofwah.or.id.

13. Nur Nurcholish Madjid., Masyarakat Religius, Mernbumikan Nilai-nilai Islam dalam Kehidupan Masyarakat, Jakarta: Paramadina, 2000, h. 96.

14. Machasin, Kebebasan Manusia, Telaah Kritis terhadap Konsepsi Al-Qur'an, Yogyakarta: INHIS. 1996, h. 55 .

15. Nurcholish Madjid, op. cit. h. 98-100.

16. Hasan Langgulung, Kreatifitas dan Pendidikan Islam, Jakarta: Pustaka Al-Husna, 19991, h. 21.

17. Hasimsyam Nasution, Filsafat Islam, Jakarta: GayaMedia Pratama, 1999, h. 201.

18. Djamaluddin Ancok, "Kualitas Masyarakat dan Pembangunan Mencari tolok Ukur Dampak Pembangunan Terhadap Kualitas Masyarakat", dalam Membangun Martabat Manusia, Yogyakarta: Gajah Mada University Press, 1996, h. 36.

19. Fran. C. Goble., Mazhab Ketiga Psikologi Humanistik Abraham Maslow, Yogyakarta: Kanisius, 1994, h. 149.

20. Nur Cholish Madjid. Masyarakat Religius, Mernbumikan nilai-nilai Islam dalam Kehidupan Masyarakat., h. 101-104-

21. Noeng Muhadjir., Ilmu Pendidikan dan Perubahan Sosial, Edisi V, Yogyakarta: Rake Sarasin. 2000, h. 7

22. Sahirul Alim, Mengenal Keterpaduan Sains, Teknotogi \& Islam., h. 28.

23. Noeng Muhadjir, Ilmu Pendidikan dan Perubahan Sosial, Edisi V h. 64.

24. Una Kartawisastra, Strategi Klasifikasi Nilai., h. 4-6.

25. Barry Chazan., Contemporary Approaches to Moral Education, Colombia University New York \& London Teachers Colge Press, t.th., h. 50.

26. Noeng Muhadjir. Ilmu Pendidikan dan Perubahan Sosial. Edisi V. h. 135.

27. Ibid., h. 48-83.

28. Mastuhu. Dinamika Sistem Pendidikan Pesantren., h. 16.

29. Ibid., h. 17.

30. Ibid., h. 17.

31. Machasin, op. cit, h. 119.

32. Ibid., h. 124.

33. Mastuhu, op. cit.,h. 27.

34. Zamroni, Paradigma Pendidikan Masa Depan, Yogyakarta: Bigraf Publishing, 2000, h. 35. 


\section{DAFTAR PUSTAKA}

Fadjar, Abdullah. "Mode/Transmisi Nilai-Nilai Islam" dalam Jurnal Ilmu Pendidikan Islam. No. 2. Vol. 1. Yogyakarta: Fak. Tarbiyah. 1991.

Abdullah, Abdurrahman Saleh. Educational Theory Aqur'anic outlook. Umm al-Qurr' University, 1982.

Asharaf, Ali. Cricis in Muslim Education. Jeddah: King Abdul Aziz University, 1398 H.

Chazan, Barry. Contemporary Approaches To Moral Education. Colombia University New York \& London Teachers Colge Press, t.th.

Departemen Agama RL, Al-Qur'an dan Terjemahnya. Jilid I, Jakarta: Proyek Pengadaan Kitab Suci. 1983/1984.

Encyclopedi Britannica, Vol. 28,

Goble, Fran. C., Mazab Ketiga Psikologi Humanistik Abraham Maslow. Yogyakarta: Kanisius, 1994.

Langgulung, Hasan. Kreatifitas dan Pendidikan Islam. Jakarta: Pustaka AI- Husna. 1991.

Nasution, Hasim Syam. Filsafat Islam. Jakarta: Gaya Media Pratama. 1999.

Ismail, dkk., Paradigma Pendidikan Islam. Yogyakarta: Pustaka Pelajar. 2001.

Ancok, Jamaludin "Kualitas Masyarakat dan Pembangunan Mencari Tolok Ukur Dampak Pembangunan Terhadap Kualitas Masyarakat", dalam Membangun Martabat Manusia, Yogyakrta: Gajah Mada University Press. 1996.

Machasin., Kebebasan Manusia, Telaah Kritis Terhadap Konsepsi Al-Qur'an. Yogyakarta: INHIS. 1996.

Miller, John. P Humanizing The Classroom. New York: Praeger Publisher Inc. 1976.

Fadjar, Malik, "Pengembangan Pendidikan Islam" dalam Kontekstualisasi Ajaran Islam. Jakarta: IPHI dan Paramadina, 1995.

Mastuhu, Dinamika Sistem Pendidikan Pesantren. Jakarta: INIS, 1994.

Syam, Muh. Noor Filsafat Pendidikan dan Dasar Filsafat Pendidikan Pancasila. Surabaya: Usaha Nasional, 1986.

Muhadjir, Noeng. llmu Pendidikan dan Perubahan Sosial. Edisi V, Yogyakarta: Rake Sarasin, 2000.

Madjid, Nurcholish. Masyarakat Religiws, Membumikan Nilai-nilai Islam dalam Kehidupan Masyarakat. Jakarta: Paramadina. 2000.

Alim, Sahirul. Menguak Keterpaduan Sains, Teknologi, dan Islam. Yogyakarta: Titian Ilahi Press, 1999.

Kartawisastra, Una, dkk. Strategi Klarifikasi Nilai. Jakarta: P3G, 1980.

Zamroni. Paradigma Pendidikan Masa Depan. Yogyakarta: Bigraf Publishing, 2000. 